\title{
China's Belt and Road Initiative Revisited
}

\author{
Challenges and Ways Forward
}

Yitzhak Shichor

\begin{abstract}
Compared with other Chinese-proposed multilateral institutions such as the Asian Infrastructure Investment Bank (AIIB) and the Shanghai Cooperation Organization (SCO), the Belt and Road Initiative (BRI) is not yet fully institutionalized. Still, it has been enthusiastically welcomed by many Asian and African countries, though less so by Western ones, Japan, and Russia. This is not only because of the expected economic benefits being Asian- and African-centric, but perhaps more importantly, because of the BRI having potential to be an exceptional Eastern model that may become universal. Up to the recent times, the flow of religions, doctrines, ideas and ideologies has mainly been from the West to the East, often accompanied by Western colonialism. Now, if the BRI is successfully implemented, for the first time in history a model of Eastern origin may affect the West and the rest of world. Unlike national liberation movements which had achieved political but not economic independence,
\end{abstract}

Yitzhak Shichor is Professor Emeritus of Asian Studies and Political Science at the Hebrew University of Jerusalem and the University of Haifa, Israel. His mailing address is: Department of Political Science, Hebrew University, Mount Scopus, Jerusalem 91905, Israel. He can be also reached at msshic@mail.huji.ac.il.

(c) 2018 World Century Publishing Corporation and Shanghai Institutes for International Studies China Quarterly of International Strategic Studies, Vol. 4, No. 1, 39-53

DOI: $10.1142 / S 237774001850001 X$

This is an Open Access article, copyright owned by the SIIS and WCPC. The article is distributed under the Creative Commons Attribution 4.0 (CC BY-NC) Licence. Further distribution of this work is permitted, provided the original work is properly cited and for non-commercial purposes. 
China's BRI could facilitate an international liberation movement that helps Asian and African countries to achieve growth and development, and thereby become economically independent as well. The innovation of the BRI does not only lie in its direction of influence (from the East to the West), but also in that it will be accomplished in Chinese rather than Western ways. That, more than particular economic benefits, explains the BRI's attraction.

Keywords: Belt and Road Initiative (BRI); slogan; model of development; East-West flow.

In my study of China for well over fifty years, I have never seen such enthusiastic welcome to any Chinese policy or idea as the Belt and Road Initiative (BRI). Within a short period of time, the "New Silk Road" vision (as it has also been called) was picked up by the Chinese and international media and discussed in scores of conferences all over the world. Even more significant and of longer value, BRI research institutes and centers have been set up in many universities. Although this initiative was launched only in late 2013, hundreds of articles and dozens of books have already been published on the topic.

This response, truly an ecstasy if not hysteria, is an unprecedented and intriguing phenomenon not only with regard to China, but also worldwide. It is intriguing because unlike other Chinese-sponsored multilateral institutions like the Asian Infrastructure Investment Bank (AIIB) and the Shanghai Cooperation Organization (SCO), the BRI is not well-defined, not well-structured, not institutionalized and is (perhaps deliberately) still quite ambiguous in many aspects. Against this backdrop, how can we explain the impassioned response from so many countries to the BRI?

In this article I shall deal less with the BRI itself and more with its reception in China and abroad (the German term is Rezeptionsgeschichte, or history of reception of ideas). To begin with, I underline the BRI's fuzzy nature, and then I offer some examples of the ways it has been received in China, around China and in the world. Next, I try to explain the reasons behind the enthusiastic response - though not always positive - to the $\mathrm{BRI}$ and point to the broad historical perspective that provides the context 
for both positive and negative responses. Finally, I make some suggestions as to how Beijing should push forward its BRI in the future. ${ }^{1}$

\section{Ambiguity and Challenges of the BRI}

It should be noted in the first place that the BRI is not a "strategy," "project" or a "plan" as is usually interpreted in most media and academic references, but it is a changyi (倡议), ${ }^{2}$ literally an "initiative" or a "proposal," a term that implies vague substance, limited commitment, and a first and initial step that is little more than a moving slogan. When the initiative was first announced in September 2013, China's state-owned People's Daily reported that "Xi Suggests China and Central Asia Build Silk Road Economic Belt (my emphasis)." ${ }^{3}$ Official Chinese sources were careful to use the term "initiative," but non-official sources and academics from within or outside China tended to use the terms "strategy" or "plan.." In short, Xi's intention may have been to put forward nothing more than a "suggestion." As it turned out, $\mathrm{Xi}$ and many Chinese leaders and policymakers were surprised by the enthusiastic welcome to his "suggestion," not just in China as could be expected, but in many other countries as well.

Unlike the AIIB, which is a well-defined and formal organization, the BRI is by and large a slogan. Occasionally, slogans are employed instead of plain words when Beijing launches new policies, both domestic and foreign, because they help simplify complicated issues in reductionist manners

${ }^{1}$ An earlier version of this article was presented at the 2017 Symposium on China Studies, organized by the PRC Ministry of Culture and the Chinese Academy of Social Sciences, Beijing, July 23-29, 2017.

${ }^{2}$ Xie Tao, “Is China's 'Belt and Road' a Strategy?," The Diplomat, December 16, 2015, https://thediplomat.com/2015/12/is-chinas-belt-and-road-a-strategy/.

${ }^{3}$ “Xi Suggests China, C. Asia Build Silk Road Economic Belt,” CRI English, September 7, 2013, http://english.cri.cn/6909/2013/09/07/2561s786481.htm.

${ }^{4}$ For the Chinese usage, see Michael D. Swaine, "Chinese Views and Commentary on the 'One Belt, One Road' Initiative," China Leadership Monitor, No. 47 (July 14, 2015) and "One Belt, One Road': China's Great Leap Outward," China Analysis (European Council on Foreign Relations, June 2015). For Western sources, see, for example Shannon Tiezzi, "China's Prescription for Troubled Xinjiang: The New Silk Road," The Diplomat, November 19, 2014, where she repeatedly uses the term "plan"; and Zhou Jiayi, Karl Hallding, and Han Guoyi, "The Trouble with China's 'One Belt One Road' Strategy," The Diplomat, June 26, 2015. 
which remain vague and thus open to diverse interpretations. All Chinese leaders since Chairman Mao have been using slogans regularly, feeling obliged to coin memorable slogans that would be associated with them. ${ }^{5}$ Following in the footsteps of Mao Zedong ("Never Forget Class Struggle"); Deng Xiaoping ("Seek Truth from Facts" and "Socialism with Chinese Characteristics"); Hu Yaobang and Zhao Ziyang ("The Early Stages of Socialism"); Jiang Zemin ("The Three Represents," "Harmonious Society") and Hu Jintao ("China's Peaceful Rise"), Xi Jinping is the copywriter of "the Chinese Dream," "a Community of Shared Future for Mankind," and the "One Belt, One Road" (OBOR or the Belt and Road Initiative). In retrospect, some of these slogans proved to be ambiguous or short-lived. To be fair, other countries - notably authoritarian ones, but Western democracies as well also use slogans, such as Washington's recent use of "Rebalancing to Asia," or "Make America Great Again," though seldom on the Chinese scale.

Behind the BRI slogan, there is very little information. On March 28, 2015, a year and a half after Xi Jinping's first proposal of the BRI, the National Development and Reform Commission (NDRC), the Ministry of Foreign Affairs (MFA) and the Ministry of Commerce (MOFCOM), authorized by the State Council, jointly published a document entitled "Vision

The BRI is China's suggestion for regional cooperation rather than a national strategy. and Actions on Jointly Building Silk Road Economic Belt and 21st Century Maritime Silk Road." Covering 16 pages, this official document is the most detailed elaboration on the BRI so far, although in actuality, it is short on specifics. ${ }^{6}$ It is a work of rhetoric art as it uses so

\footnotetext{
${ }^{5}$ Robert Denton, “The Rhetorical Functions of Slogans: Classifications and Characteristics," Communication Quarterly, 28 (1980), pp. 10-18; Charles Stewart, C.A. Smith, and Robert Denton, Jr. "The Persuasive Functions of Slogans," in Robert Jackall, ed., Propaganda (New York: New York University Press, 1995), pp. 400-422; and Lu Xing, "An Ideological/ Cultural Analysis of Political Slogans in Communist China," Discourse E Society, Vol. 10, No. 4 (1999), pp. 487-508. See also: Henry Yuhuai He, Dictionary of the Political Thought of the People's Republic of China (Armonk, NY: M.E. Sharpe, 2001); and Li Gucheng, A Glossary of Political Terms of the People's Republic of China (Hong Kong: Chinese University Press, 1995).

6"Vision and Actions on Jointly Building Silk Road Economic Belt and 21st-Century Maritime Silk Road," National Development and Reform Commission, March 28, 2015, http://en.ndrc.gov.cn/newsrelease/201503/t20150330_669367.html.
} 
many words to say so little. Exceptionally broad and general, the BRI covers whatever ordinary international economic relations cover anyway. It offers nothing about the BRI structure, except that it will use existing mechanisms such as the China-Arab States Cooperation Forum, Shanghai Cooperation Organization, ASEAN plus China $(10+1)$, Asia-Pacific Economic Cooperation (APEC), Asia-Europe Meeting (ASEM), Asia Cooperation Dialogue (ACD), China-Gulf Cooperation Council Strategic Dialogue and a few more. It gives little, if any, precise information about financial commitments and fails to identify precisely the countries involved or to provide official maps. The BRI is mentioned only three times in the Chinese version (21 pages) of Xi Jinping's Report to the 19th National Congress of the Communist Party of China (CPC) held on October 18, 2017, and five times in the English version (65 pages).

But that is not all. The ambiguity of the BRI hides or downplays considerable challenges. A keyword that appears most frequently in the 16-page document is "cooperation" (98 times). Many nations - perhaps too many - and Chinese provinces and agencies are encouraged to be involved in the BRI's decision-making and implementation processes. It may lead to difficult and frustrating efforts to manage and coordinate the BRI's activities, regarded by the Chinese as a precondition for success of the initiative. "As long as all countries along the Belt and Road make concerted efforts to pursue our common goal, there will be bright prospects for the Silk Road Economic Belt and the 21st-Century Maritime Silk Road." ${ }^{7}$ In addition, the BRI practically ignores a variety of obstacles and risks along the routes, both on land and at sea, including piracy, terrorism, Islamic extremism, ethnic and national rivalries, internal and interstate violence, to name only a few. As the BRI proceeds, those challenges may disrupt the movement of investments, goods and people at unexpected times.

\section{Mixed Reactions to the BRI}

Despite the BRI's ambiguity and challenges, the initiative has been enthusiastically applauded not only in China itself, but also in the region and all over the world. It is somewhat funny to watch how many countries 
consider themselves as a "crossroads," a "key," or a "hub," in China's BRI, assuming self-importance in it.

Since the BRI was announced, thousands of articles have appeared in Chinese academic journals according to China National Knowledge Infrastructure (CNKI). As of December 13, 2015, "an astonishing 2,735" entries had been published, indicating a "nationwide craze over the Belt and Road." ${ }^{8}$ Furthermore, some of them had thousands of downloads, which multiplied their readership on a huge scale. ${ }^{9}$ In addition to the articles, scores of books ${ }^{10}$ and chapters in edited volumes were also published, and a number of research centers and institutes established in Chinese universities, such as Qingdao University's Belt and Road Research Institute; the Silk Road Research Institute at Beijing Foreign Studies University; and the

${ }^{8}$ Xie Tao, "Is China's 'Belt and Road' a Strategy?"

${ }^{9}$ For example, according to CNKI data, an article by Kong Qingfeng and Dong Hongwei, "Yidaiyiluguojia de maoyibianlihua shuipingcesuan yu maoyiqianli yanjiu (Trade Facilitation and Trade Potential of Countries along the 'One Belt One Road')," Guoji Maoyi Wenti [Issues in Foreign Trade], No. 12 (2015), pp. 158-168, was downloaded 8,038 times; and Lin Minwang's article, "Indu dui 'yidaiyilu' de renzhi ji zhongguo de zhengcexuanze (Indian Perceptions of 'One Belt One Road' and China's Policy Choices," World Economics and Politics, No. 5 (2015), was downloaded 12,375 times.

${ }^{10}$ For example Li Ping and Liu Qiang, One Belt And One Road Strategy: Development of Energy Infrastructure and Integration of Energy Market in Asia-Pacific Region (Beijing: China Social Sciences Press, 2015); Feng Bing, One Belt and One Road: The Chinese Logic for Global Development (Beijing: China Democracy \& Rule of Law Publishing House, 2015); Liu Wei, The Belt and Road Initiative (Shanghai: Jiao Tong University Press, 2015); Li Xiaopeng, From Yellow River Civilization to the Belt And Road Initiative, Vol. 1 (Beijing: China Development Press, 2015); Yang Yiwei, The Belt and Road Initiatives (Opportunity and Challenge) (Beijing: People's Publishing House, 2015); Lin Yifu and Jin Liqun, One Belt One Road (Beijing: China Literature and History Press, 2015); Zhao Jianglin, The 21st Century Maritime Silk Road: Target, Implementation and Policy Suggestions (Beijing: Social Science Academic Press, 2015); Wang Yiwei, The Belt and Road: What Will China Offer the World in Its Rise (Beijing: New World Press, 2016); Wang Yiwei, The World Is Connected: The Logic of The Belt and Road Initiative (Beijing: The Commercial Press, 2016); Liu Weidong, Tian Jinchen and Ou Xiaoli, The Belt and Road Initiative Strategy Research/Monographic Study on "The Belt and Road Initiative" (Beijing: The Commercial Press, 2017); Zhao Lei, The Annual Report on One Belt One Road 2017 (Beijing: The Commercial Press, 2017); and Ding Yani, Huang Mengting, and Huang Rong, A Data-Based Explanation of One Belt One Road (Beijing: The Commercial Press, 2016). This is a small sample of Chinese books on the BRI. 
Center of Silk Road Economic Belt Research at Xi'an Jiaotong University, among others.

BRI research has

enjoyed explosive

popularity in China.
Meanwhile, many "Belt and Road" and "New Silk Road" conferences were held in China. I helped organize one of them which became the launching event of the new Middle East Center at the Guangzhou and Zhuhai Campus of Sun Yat-sen University. Held from January 2-4, 2017, this Middle East Studies International Workshop, in which all the participants came from the Middle East and China, focused on the BRI in a Middle Eastern context. An international conference on "China's One Belt One Road Initiative: Past, Present and Future" was held on October 15, 2016, at the Nottingham Confucius Institute China, Ningbo Branch, organized by the University of Nottingham in Ningbo, China. The "One Belt, One Road" Institute of the Center for China and Globalization (CCG) in Beijing held a seminar on November 9, 2015, on the relations between "One Belt, One Road" and the Washington-promoted Trans-Pacific Partnership (TPP). This wave reached a peak in May 14-15, 2017, when China convened "The Belt and Road Forum for International Cooperation" in Beijing. More than 29 heads of state and government as well as representatives from over 130 countries and 70 international organizations participated. Such a welcome for the BRI within China is understandable and was, in fact, expected. A similar response from abroad was less so.

As it turned out, external interest in the BRI, both regional and from afar, was equally overwhelming. Hong Kong, a Special Administrative Region of China, has been one of the leaders of this interest. For example, a conference on "LMS on OBOR" was held by the Department of Logistics and Maritime Studies of the Hong Kong Polytechnic University from May 10-11, 2016; a "Belt and Road Summit" was held at the Hong Kong Convention and Exhibition Centre on May 18, 2016; and a "China Conference - One Belt One Road" was hosted by the South China Morning Post on December 2, 2016.

Interest in the BRI has been significant even further away from China. For example, a conference on "One Belt, One Road and a Prosperous Africa" was held at Durban University of Technology (South Africa) from November 19-20, 2015; an international conference on "The Silk Road Economic Belt and the 21st-Century Maritime Silk Road for Transportation 
and Global Supply Chain" was held at Victoria University, Melbourne, from December 1-2, 2016; Aalborg University in Denmark held an international workshop on China's “'One Belt, One Road' Global Strategy: Implications, Prospects and Constraints" from January 19-20, 2017. Besides, according to Amazon.com, by July 2017, and in less than four years, 120 books on the BRI have been published all over the world, in addition to the hundreds of articles published worldwide according to Google Scholar.

Nonetheless, there are differences in the way the BRI has been received. Russia appears to be less enthusiastic about China's BRI. In fact, compared with the multitude of articles, studies and commentaries on this issue published elsewhere, relatively few have been published in Russia. As people see it, "Some Russian media also have been highlighting the dangers of the Belt and Road program conflicting with Moscow's Eurasia initiative and helping China overtake Russia for influence among Central Asian countries." 11

The Central Asian republics have displayed similar concern about China's economic penetration in the region, for they still remember the much longer and the directly coercive Soviet rule; Russia's aggressive policy in Georgia, the Crimea and Ukraine (which Beijing found hard to swallow) has further

Western countries and some of China's neighbors tend to be more critical about the BRI. alarmed Central Asia. Thus, many Kazakhs display "Sinophobic feelings" and "alarmist" views about China's economic penetration, primarily regarding labor disputes and the influx of better-paid Chinese workers. Also, some believe that the BRI would

${ }^{11}$ Saibal Dasgupta, “China's Ambitious 'Silk Road' Plan Faces Hurdles," Voice of America, April 15, 2015, https://www.voanews.com/a/chinas-ambitious-silk-road-planfaces-hurdles/2719660.html. See also Casey Michel, "Putin's Eurasian Union Doomed to Irrelevance by China's Silk Road," World Politics Review, October 5, 2015, https://www. worldpoliticsreview.com/articles/16858/putin-s-eurasian-union-doomed-to-irrelevance-bychina-s-silk-road; and Catherine Putz, "China's Silk Road Belt Outpaces Russia's Economic Union," the Diplomat, March 10, 2016, https:/thediplomat.com/2016/03/chinas-silk-road-beltoutpaces-russias-economic-union/. According to Alexander Cooley of Columbia University's Harriman Institute, these two projects are "conceptually incompatible." See Sebastien Peyrouse, "The Evolution of Russia's Views on the Belt and Road Initiative," Asian Policy, No. 24 (July 2017), pp. 96-102. 
compete with the Russian-sponsored Eurasian Economic Union (EEU) inaugurated in early 2015, of which Kazakhstan is a member along with four other countries. Nevertheless, the EEU membership and the public anxiety against Beijing by no means imply that the BRI is rejected. Kazakhstan's public attitude toward the BRI and - needless to say - Astana's official policy are fundamentally positive. "The positive attitude is dominant in spite of the presence of Sinophobic sentiments in Kazakhstan, which in turn do not have a solid ground and mostly based on myths." ${ }^{12}$ This is typical of Central Asia whose prospective benefits from the BRI overshadow their concerns about China's economic penetration.

The United States, Western Europe and Japan appeared to have adopted a positive attitude toward China's BRI at the beginning, both because they thought the BRI could help promote Chinese overseas investment, especially in infrastructure, and thus enhance regional inter-connectivity, and also because they expected the BRI to engage China more deeply in established regional norms and institutions. However, this positive attitude has been waning as China attempts to engage countries along the Belt and Road via a one-on-one approach, and it seems to be withdrawing some of its past commitments on funding and domestic market access. As a result, many articles and commentaries underline the difficulties, hurdles and bumps on the BRI, even to the point of predicting its failure. ${ }^{13}$

\section{Significance of the BRI in Historical Perspective}

Given the BRI's uncertainties, obstacles and risks, how can we explain its ecstatic reception, primarily by Asian and African countries? Obviously,

${ }^{12}$ This paragraph draws on Azhar Serikkaliyeva, "Public Perception of the 'One Belt One Road' Initiative in Kazakhstan," Eurasian Research Institute (Akhmet Yassawi University, February 23, 2016). See also K. Syroezhkin, “China's Presence in Kazakhstan: Myth and Reality," Central Asia's Affairs, Vol. 1, No. 42 (2011).

${ }^{13}$ The Economist Intelligence Unit, "Prospects and Challenges on China's 'One Belt, One Road': A Risk Assessment Report," https://www.eiu.com/public/topical_report.aspx?campaignid=OneBeltOneRoad; Moritz Rudolf, "China's 'Silk Road' Initiative is at Risk of Failure," The Diplomat, September 24, 2015, https:/thediplomat.com/2015/09/chinas-silk-roadinitiative-is-at-risk-of-failure/; and Shen Laijin and Huang He, "Riben dui 'yidaiyilu'changyi de renzhi jiqi dui zhonguo de qishi [Japan's Cognition of The 'One Belt and One Road' Initiative and its Enlightenment to China]," Socialism Studies, No. 2 (2017), pp. 149-153. 
these Asian and African countries embrace the BRI because they expect to benefit from the initiative either economically or in other aspects - in other words, to "win." In comparison, Western Europe, Japan, Russia and the United States may perceive the BRI as a potential challenge to their respective economic, political or geostrategic interests. Yet to me, the roots of these different attitudes are far beyond the consideration of "winning" or "losing," especially since everyone is going to win ultimately as the Chinese leaders keep reiterating. As a matter of fact, the BRI is the first worldwide constructive initiative by an "Eastern" nation ever. To be sure, this is not the first time that an "Eastern" entity has attempted to leave an impact on the West. In the 13th and 14th Centuries, the Mongols provided the only other example of expansion from East Asia to Central Asia and all the way to Europe along the continental Silk Road, but it was a destructive military advance. The Chinese BRI, which follows the same land route and targets the same population, is by and large an economic enterprise and is constructive. Asia had made some noteworthy contributions to the West, including the Indo-European languages, inventions that are still in use, and influences on Europe's philosophers, statesmen and daily life during the 17th and 18th Centuries remembered as the Age of Enlightenment, not to mention Silk Road trade. But all of these could be dwarfed by the potential tangible effects of the BRI.

Japan, the only other "Eastern" great power whose credentials were primarily economic, very much like China's today, and which reached its apex in the 1980s as second only to the United States, very much like China is today, has never introduced an initiative or any multi-regional economic plan of the BRI's scale. Instead, it has offered assistance on a piecemeal basis at best. Though associated with Japan, the Asian Development Bank (ADB), which could have been the source of an initiative similar to the BRI, is a multilateral enterprise which often reflects the interests of Western powers headed by the United States, and primarily Japan. ${ }^{14}$ India, another

${ }^{14}$ For example Jonathan R. Strand, "State Power in a Multilateral Context: Voting Strength in the Asian Developing Bank," International Interactions, Vol. 25, No. 3 (1995), pp. 265-286; Christopher Kilby, "Donor Influence in Multilateral Development Banks: The Case of the Asian Development Bank," Review of International Organizations, Vol. 1, No. 2 (2006), pp. 173-195; and Daniel Yew Mao Lim and James Raymond Vreeland, "Regional Organizations and International Politics: Japanese Influence over the Asian Development Bank and the UN Security Council," World Politics, Vol. 65, No. 1 (January 2013), pp. 34-72. 
emerging economic power, has never had the resources nor the will or experience to come up with a BRI-like initiative. Likewise, none of the energy-rich Arab nations has ever tried to use its abundant resources to promote the economic development and growth of other nations - least of all their kin in the Middle East.

The significance of the BRI does not derive from its size and goals, which are still unclear and yet to be accomplished, but from its historical context. President Xi Jinping may have not thought about it or foreseen it when he first proposed the BRI. Nonetheless, the BRI seems to be the first comprehensive answer to the legacy of colonialism from both the West and the East (Russia and Japan). This better explains the ecstatic response in Asia and Africa, as compared to the constrained and qualified reception in Europe, Russia, Japan and the United States. Unlike the legacy of colonialism, which did bring about some level of economic development and investment in infrastructure (mainly for facilitating political control and military presence), the BRI offers economic benefits without political and military involvement. This is not to say that the Chinese are totally innocent of intervention (contrary to the conventional belief based on Beijing's own statements). China does intervene - but in Chinese ways, which I termed "active passivity" or "passive activism." 15

However, Western observers and academics, in particular American ones or those educated in American universities and research institutions, tend to interpret Beijing's activism abroad in Cold War terms, the only terms they are familiar with. Thus, Western media and experts frequently associate the BRI (often referring to it wrongly as a "plan," "strategy," "project" or "policy") with Beijing's alleged pursuit of political control, predominance and influence, a strategic foothold accomplished by a buildup of "naval bases" and railroads abroad. These reflect a gross misunderstanding of China's history, culture, military capabilities and, even more so, intentions. In fact, in his report to the 19th CPC National Congress,

${ }^{15}$ Yitzhak Shichor, "Fundamentally Unacceptable Yet Occasionally Unavoidable: China's Options on External Intervention in the Middle East," China Report, Vol. 49, No. 1 (2013), pp. 25-41. 
Xi Jinping underlined that China will "resolutely reject the Cold War mentality and power politics." ${ }^{16}$

To highlight the importance of a historical perspective, it should be remembered that the flow of religions, ideas and models across the vast Eurasian continent has been almost without exception from the West to the East, such as Christianity, Islam, capitalism, socialism, communism and democracy, among others. Few Eastern ideas or religious beliefs spread to the West, except for some elements of Buddhism and a few inventions. Throughout its history, Chinese civilization and dy-

The BRI is embraced by developing nations as it represents an unprecedented Eastern model of regional cooperation. nasties have avoided and rejected missionary policies. Those who wanted to learn Chinese ways had to go to China. China had never advertised. Even at the peak of the frenzied Cultural Revolution (1966-1976), the Chinese government did not try to promote Maoism abroad. Indeed, for a while in the 1960s, some radicals including intellectuals and academics mainly in the United States, Western Europe and South America became highly intoxicated by Maoism. Yet this was by no means an outcome of Beijing's propagation of Maoism abroad. Now, the BRI, along with the "China model" and the "Beijing consensus," represents the first, though still initial, flow of ideas from the East to the West. It is not only about economics, but also about a more comprehensive model of cooperation among nations on development, even in cultural and political aspects. It is no wonder the West is reluctant to accept, let alone adopt, the Chinese initiative.

\section{Advancing the BRI}

Although most formerly colonized Asian and African nations did eventually win political independence through successful struggles of their

${ }^{16} \mathrm{Xi}$ Jinping, "Secure a Decisive Victory in Building a Moderately Prosperous Society in All Respects and Strive for the Great Success of Socialism with Chinese Characteristics for a New Era," October 18, 2017, p. 53, http://www.xinhuanet.com/english/download/Xi_Jinping \%27s_report_at_19th_CPC_National_Congress.pdf. 
national liberation movements, many of them still depend economically on their former colonizers either directly or indirectly, subjected to the goodwill of international financial organizations such as the World Bank (WB), the ADB and the International Monetary Fund (IMF), all under the control of Western countries. In this sense, the BRI and the AIIB could be a spearhead of an "international liberation movement," the first large-scale attempt in history, to release those countries - many of them rich in natural resources - from their economic dependence on the West, with no strings attached.

As mentioned previously, the BRI is not just an economic vision; there is little doubt that Beijing is also pursuing political goals not unlike the other powers, both in the East and in the West, although substantially less brutally, and definitely not militarily. This unique endeavor in human history should not be frivolously dismissed. Most importantly, China should not repeat the mistakes of colonial powers of the past and must avoid the Cold War mentality of expanding its military presence and spreading military bases all over the world. Economic development is the key and it should be divorced from politics. In 2005, then U.S. Deputy Secretary of State Robert Zoellick said that China should become "a responsible stakeholder" and play a more important and active role in international politics. ${ }^{17}$ Various interpretations have been offered for the precise meaning of this term, but whatever they are, they have to do with politics. He is not alone. His views have been echoed not just in the West as well as in Third World countries, but also among some Chinese scholars, especially those educated in the United States. ${ }^{18}$ Most of them lived their adult life during

17Julia Bowie, “China: A Responsible Stakeholder?,” The National Interest, May 10, 2016, http://nationalinterest.org/blog/the-buzz/china-responsible-stakeholder-16131.

${ }^{18}$ For example Yan Xuetong, "From Keeping a Low Profile to Striving for Achievement," The Chinese Journal of International Politics, Vol. 7, No. 2 (June 2014), pp. 153-184; Ling Shengli, "Cong 'canyuzhe' dao 'jianshezhe' — zhongguo canyu guojizhengzhi anquanxiti de jinchengfenxi [From 'Participant' to 'Constructor' — An Analysis of China's Participation in the International Political and Security System]," Peace and Development, No. 4 (2016), pp. 7-17; and He Kai and Feng Huiyun, “Debating China's Assertiveness: Taking China's Power and Interests Seriously," International Politics, No. 49 (2012), pp. 633-644. 
the Cold War and, willingly or unwillingly, absorbed its ethos that global predominance relies on intervention, military presence and coercion.

However, this is not necessarily the right way to do it, not only because the Cold War is practically over and its ethos may have proved a failure (certainly from Moscow's standpoint), but primarily because China has its own ethos, which relies on its own historical experience, cultural values and diplomatic models. China's modern experience, especially since the launch of post-Mao reform, shows that China's inter-

China must stick to its own way and focus on economic cooperation in pushing forward the BRI. national as well as domestic goals could be achieved in different ways from the West, which are more constructive and less disruptive to the established social order. Behind the warm welcome to the BRI, especially from the Third World countries, there is a common expectation for China to play a greater role in the world in economic arenas, yet much less in political ones.

Indeed, China's record in contributing to the solution of international political issues is quite marginal - and for good reasons. China does not want to become involved in international conflicts which, it believes, should be resolved by the parties directly concerned. Willingly or not, participating in conflict settlement implies taking sides. For a variety of reasons, Beijing prefers not to identify with one party against the other, as seen from its neutral stance toward Iran-Saudi Arabia, Turkey-Syria, Israel-Palestine, or Kazakhstan-Uzbekistan conflicts. Despite the diplomatic tools Beijing has acquired since the early 1970s, such as the permanent membership in the United Nations Security Council (UNSC), an extensive network of diplomatic relations, and membership in many international institutions including its recent leadership in the Group of Twenty (G20) or the BRICS (a cooperative platform among Brazil, Russia, India, China and South Africa), it has seldom been actively involved in settling salient political conflicts.

Nevertheless, Beijing has been directly and effectively involved in a variety of economic ventures, with the BRI being the most promising. Contrary to the commonly held view of China's "non-interventionism," Beijing often does intervene, but in Chinese rather than Western ways. This is not just a reincarnation of traditional Chinese values. It also conforms to a 
basic Marxist principle: economic development and growth creates sociopolitical problems but might also help overcome them, as compared to reliance on direct political or, least of all, military intervention. If Beijing wants to guarantee the future success of the BRI, it should continue to adopt Chinese ways and always remain cautious to avoid the trap of foreign approaches. 